\title{
Micropropagation of Stevia rebaudiana plants
}

\author{
Marta Teresa Rokosa ${ }^{*}$ (D) Danuta Kulpa ${ }^{2}$ (D) \\ ${ }^{1}$ Laboratory of Plant Physiology and Entomology, Department of Bioengineering, Faculty of Environmental Management and Agriculture, West \\ Pomeranian University of Technology in Szczecin, ul. Juliusza Słowackiego 1770-953 Szczecin, Poland. E-mail: marta.rokosa@zut.edu.pl. \\ ${ }^{*}$ Corresponding author. \\ ${ }^{2}$ Department of Genetics, Plant Breeding and Biotechnology, Faculty of Environmental Management and Agriculture West Pomeranian \\ University of Technology in Szczecin, Szczecin, Poland.
}

ABSTRACT: The aim of the study was to develop optimum composition of plant growth regulators in media for the propagation and rooting of shoots of stevia (Stevia rebaudiana Bertoni) in in vitro cultures. Single-node shoot fragments obtained from plants propagated on MS medium were placed onto media supplemented with: BAP, 2iP and KIN at concentrations: $0.5,1,2$ and 5 mg.dm-3 whereas at the rooting stage with addition of: IAA, IBA and NAA at concentrations 1, 2, 4 and $8 \mathrm{mg} \cdot \mathrm{dm}^{-3}$. The highest number of shoots and leaves was reported for plants propagated on MS medium enriched with $0.5 \mathrm{mg} \cdot \mathrm{dm}^{-3} \mathrm{BAP}$. The greatest number of the longest roots was developed by stevia on the MS medium enriched with $1 \mathrm{mg} \cdot \mathrm{dm}^{-3} \mathrm{IAA}$.

Key words: micropropagation, plant growth regulators, cytokinins, auxins, steviosides.

Micropropagação de plantas de Stevia rebaudiana

RESUMO: $O$ objetivo do estudo foi desenvolver uma composição ótima de reguladores de crescimento em meios para a propagação e enraizamento de brotos de estévia (Stevia rebaudiana Bertoni) em culturas in vitro. Fragmentos de parte aérea obtidos de plantas propagadas em meio MS foram colocados em meio suplementado com: BAP, 2iP e KIN nas concentrações: $0.5,1,2$ e 5 mg.dm-3 enquanto no estádio de enraizamento com adição de: IAA, IBA e ANA nas concentrações 1, 2, 4 e $8 \mathrm{mg} \cdot \mathrm{dm}^{-3}$. O maior número de brotações e folhas foi encontrado para plantas propagadas em meio MS enriquecido com $0.5 \mathrm{mg} \cdot \mathrm{dm}^{-3}$ de BAP. O maior número de raizes mais longas foi desenvolvido por estévia no meio $\mathrm{MS}$ enriquecido com $1 \mathrm{mg} \cdot \mathrm{dm}^{-3}$ de IAA.

Palavras-chave: micropropagação, reguladores de crescimento de plantas, citocininas, auxinas, esteviosídeos.

\section{INTRODUCTION}

Stevia rebaudiana Bertoni is a plant belongs to the Asteraceae family. It is a shrub growing to 80 $\mathrm{cm}$ height, having leaves with a lanceolate shape. The stem is woody, the flowers are abundant and possess white-violet color (LEMUS-MONDACA et al., 2012). Its leaves contain diterpene glycosides, such as steviosides, rebaudiosides, rubosides steviolbiosides and dulcosides, the sweetness of which is up to 300 -fold higher than traditional sugar and thus it is known as sweet leaf (BONDAREV et al., 2001, DASI et al., 2011, GANTAIT et al., 2015, GEUNS, 2003, LEMUS-MONDACA et al., 2012, SIVARAM \& MUKUNDAN, 2003). In many countries, stevia is used as a healthier substitute for cane or beet sugar, commonly used to sweeten many dishes. The plant has been used in the area of its origin (South
America) to sweeten various food products, including seafood, marinated vegetables, desserts, beverages and confectionery for centuries (KHAN et al., 2013). The sweetener produced from stevia leaves, contrary to typical sucrose, is low in calories and low-glycemic, thus it is recommended for persons with diabetes (BESPALHOK-FILHO \& HATTORI, 1997, GOETTEMOELLER - LUCKE, 2010). Sweetening substances present in stevia did not cause dental caries (MATHUR - SHEKHAWAT, 2013).

Moreover, stevia leaves contain alkaloids, flavonoids, water-soluble chlorophylls and xanthophylls, hydroxycinnamic acids (caffeic, chlorogenic etc.), water-soluble inert oligosaccharides, free sugars, amino acids, lipids, essential oils, trace elements, vitamins, polyphenols and other antioxidants (CARBONELL-CAPELLA et al., 2013, TAVARINI \& ANGELINI, 2013). 
In addition, $S$. rebaudiana leaf extract has antibacterial and fungicidal properties, with an inhibitory effect on the growth of such bacteria as Staphylococcus aureus, Streptococcus mutans, Bacillus subtilis and Escherichia coli (RAZAK et al., 2014). Moreover, its antihypertensive, antiinflammatory, anti-cancer, antidiarrheal, diuretic and immunomodulatory properties have been demonstrated (CARBONELL-CAPELLA et al., 2013). In vitro and in vivo studies carried out on humans and animals under the WHO (World Health Organization) supervision, demonstrated that consumption of steviosides and rebaudiosides did not induce mutagenicity, teratogenicity, and carcinogenicity (LEMUS-MONDACA et al., 2012, KHALIL et al., 2014).

Considering its valuable properties, as well as highly impeded traditional stevia propagation methods (seeds demonstrate very low germination percentage, and the progeny plants exhibit high variability in terms of chemical composition and sweetness level), the need for development of an efficient method for mass clonal propagation of stevia in in vitro conditions appears to be valid (SOLIMAN, 2014, NOWER, 2014, KUMAR, 2013, DESHMUKH \& ADE, 2012, ANBAZHAGAN et al. 2010, PANICKER et al. 2007, HWANG, 2006, SIVARAM \& MUKUNDAN, 2003). However, in order for this to be possible, the parameters of the conducted culture must be precisely determined, and in particular the content of plant growth regulators in the medium. Research should be conducted on the effects of different concentrations of plant growth regulators on the growth and development of stevia. Currently, there are no studies using the factors and conditions used in this study. Thus, the objective of this study was to determine the impact of selected growth regulators on the propagation and rooting of stevia plants in in vitro cultures.

\section{MATERIALS AND METHODS}

Initiation stage. Stevia seeds (Vilmorin Clause \& Cie, Paris, France) constituted the study material. For the purpose of disinfection, the seeds were soaked in water with the addition of detergentLudwik for 20 minutes. Subsequently, they were rinsed several times under running water and immersed for 30 seconds in $70 \%$ ethanol solution. Initially disinfected seeds were shaken in $10 \%$ sodium hypochlorite solution for 15 minutes and were rinsed three times with sterile water. Then were placed individually to $15 \mathrm{ml}$ test tubes containing $3 \mathrm{ml}$
MS medium (Murashige and Skoog, 1962). Thus obtained sterile shoots, propagated several times on MS medium constituted the population for the establishment of the subsequent experiment.

\section{Propagation stage}

In the subsequent stage, $1 \mathrm{~cm}$ long single-node shoots were placed on MS media with $0.5,1,2$ or $5 \mathrm{mg} \cdot \mathrm{dm}^{-3}$ addition of cytokinins: BAP (6-benzyl aminopurine), 2iP (2-isopentyladenine) or KIN (kinetin). Twenty passages were carried out to multiply plant material.

\section{Rooting stage}

The $1 \mathrm{~cm}$ long nodal fragments was taken from plant originated from propagation phase, and were placed onto MS media supplemented with auxins: IAA (indole-3-acetic acid), IBA (indole-3butyric acid) and NAA (1-naphthaleneacetic acid) at concentrations 1, 2, 4 and $8 \mathrm{mg} \cdot \mathrm{dm}^{-3}$. Explants placed onto MS medium without addition of plant growth regulators constituted control in both experiments.

At all study stages, the $\mathrm{pH}$ of media was set at 5.7 using $0.1 \mathrm{M}$ solutions of hydrochloric acid $(\mathrm{HCl})$ sodium hydroxide $(\mathrm{NaOH})$. Media were supplemented with $8 \mathrm{~g} \cdot \mathrm{dm}^{-3}$ agar (media were gelled), $30 \mathrm{~g} \cdot \mathrm{dm}^{-3}$ sucrose and $100 \mathrm{mg} \cdot \mathrm{dm}^{-3}$ inositol. The cultures were carried out in $300 \mathrm{ml}$ jars, each containing $30 \mathrm{ml}$, which were sterilized at $121{ }^{\circ} \mathrm{C}$ for $20 \mathrm{~min}$. To each jar, 6 explants were introduced and each combination comprised of 7 jars. The established cultures were placed in a growth chamber, on shelves illuminated with white light for 16 hours, at $40 \mu \mathrm{mol} \cdot \mathrm{m}^{-2} \cdot \mathrm{s}^{-1} \mathrm{PAR}$ intensity, temperature $25 \pm 1{ }^{\circ} \mathrm{C}$. After 5 weeks the number and length $[\mathrm{cm}]$ of shoots, number, and length $[\mathrm{cm}]$ of roots, as well as plant weight $[\mathrm{g}]$, were determined.

\section{Statistical analysis}

Results of biometric measurements were analyzed using ANOVA and the significance of differences at $\alpha=0.05$ between the tested media was assessed by means of Tukey test.

\section{RESULTS AND DISCUSSION}

\section{Propagation stage}

The study allowed to demonstrate the addition of BAP and 2iP cytokinins influenced the increase in the number of side shoots. Their highest number was reported for media supplemented with 0.5 and $1 \mathrm{mg} \cdot \mathrm{dm}^{-3}$ BAP (Figure 1)-close to two-fold 


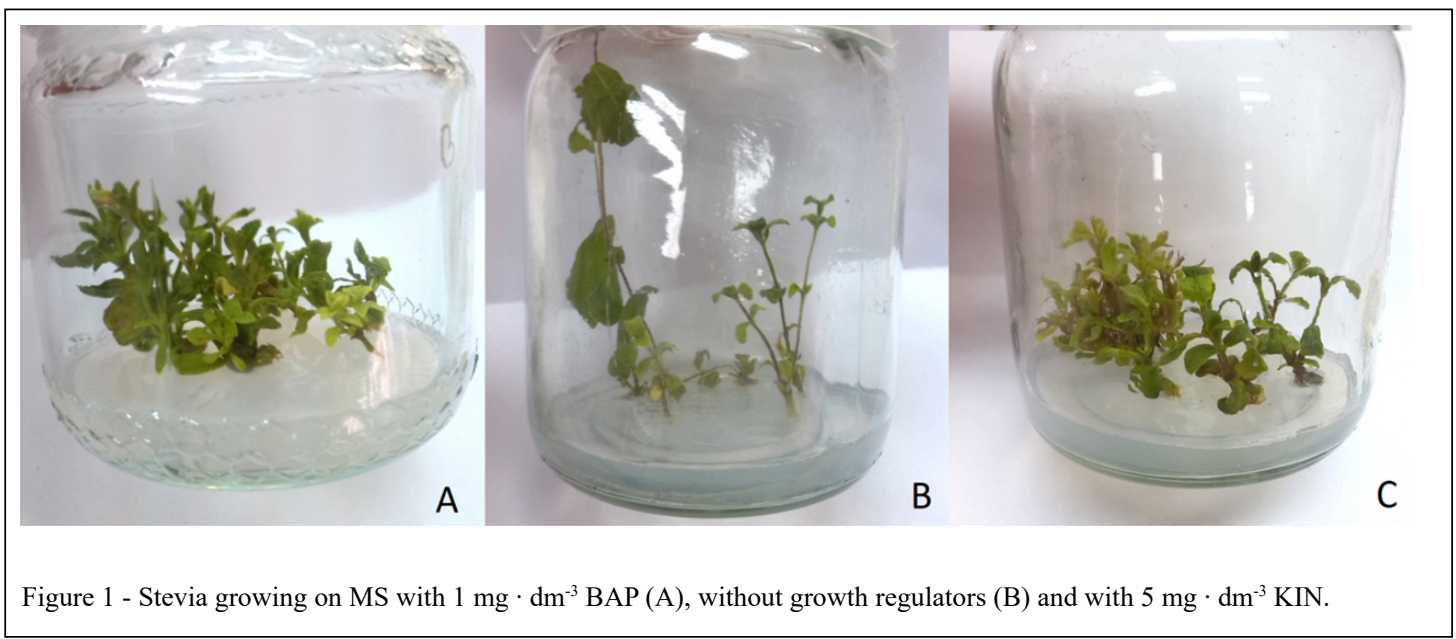

higher compared to plants propagated on control medium. With the increase of BAP concentration, the number of produced shoots decreased. A reverse tendency was observed for KIN, where its increased concentration resulted in the formation of a higher number of shoots. Plants propagated on media with the addition of cytokinins produced a higher number of leaves (from 12.06 to 21.17) relative to control plants (9.60). The exception consisted of plants propagated on media with the addition of the lowest KIN concentrations $\left(0.5\right.$ and $\left.1.0 \mathrm{mg} \cdot \mathrm{dm}^{-3}\right)$. The highest number of leaves was determined in the case of the lowest BAP concentration $\left(0.5\right.$ and $\left.1 \mathrm{mg} \cdot \mathrm{dm}^{-3}\right)$ (Table 1$)$.
The major properties of cytokinins are: stimulation of cell division and release of lateral bud dormancy (GASPAR et. al., 1996). Based on the completed study, it can be determined that addition of cytokinins to media has a stimulatory effect on the formation of the above-ground parts of stevia (Stevia rebaudiana Bertoni) plants-under their influence, the number of shoots and leaves has typically increased. An identical result was obtained by Nower (2014), where plants growing on media enriched with BAP at 0.5 and $1 \mathrm{mg} \cdot \mathrm{dm}^{-3}$ concentration produced the highest number of shoots. Moreover, the study of ZAYOVA et al. (2013) demonstrated that a medium with the

Table 1 - Mean values of morphological characters of plants propagated on media with variable cytokinin content.

\begin{tabular}{|c|c|c|c|c|c|c|c|c|c|c|c|c|}
\hline \multirow{2}{*}{$\begin{array}{l}\text { Cytokinin concentration } \\
{\left[\mathrm{mg} \cdot \mathrm{dm}^{-3}\right]} \\
\text { MS }\end{array}$} & \multicolumn{2}{|c|}{$\begin{array}{c}\text { Length of } \\
\text { shoots }[\mathrm{cm}]\end{array}$} & \multicolumn{2}{|c|}{$\begin{array}{l}\text { No. of } \\
\text { shoots }\end{array}$} & \multicolumn{2}{|c|}{ No. of leaves } & \multicolumn{2}{|c|}{ Fresh weight $[\mathrm{g}]$} & \multicolumn{2}{|c|}{ No. of roots } & \multicolumn{2}{|c|}{$\begin{array}{l}\text { Length of } \\
\text { roots }[\mathrm{cm}]\end{array}$} \\
\hline & 2.80 & $b^{*}$ & 1.42 & $\mathrm{e}$ & 9.60 & $\mathrm{~g}$ & 0.053 & $\mathrm{f}$ & 0.64 & $\mathrm{bc}$ & 0.29 & $\mathrm{~cd}$ \\
\hline 0.5 & 2.78 & $\mathrm{~b}$ & 3.04 & $\mathrm{a}$ & 19.04 & $a b$ & 0.157 & $a b$ & 0.40 & bcd & 0.13 & $\mathrm{de}$ \\
\hline BAP & 2.42 & $\mathrm{c}$ & 3.38 & $\mathrm{a}$ & 21.17 & $\mathrm{a}$ & 0.157 & $\mathrm{a}$ & 0.00 & $\mathrm{e}$ & 0.00 & $\mathrm{e}$ \\
\hline 2 & 1.90 & $\mathrm{f}$ & 2.63 & $\mathrm{~b}$ & 17.08 & $\mathrm{bc}$ & 0.124 & $\mathrm{~cd}$ & 0.00 & e & 0.00 & $\mathrm{e}$ \\
\hline 5 & 2.14 & $\mathrm{de}$ & 2.37 & $\mathrm{~b}$ & 13.61 & $\mathrm{~d}$ & 0.100 & de & 0.00 & $\mathrm{e}$ & 0.00 & $\mathrm{e}$ \\
\hline 0.5 & 2.96 & $\mathrm{~b}$ & 2.17 & $\mathrm{c}$ & 14.88 & $\mathrm{c}$ & 0.167 & $\mathrm{a}$ & 0.00 & e & 0.00 & $\mathrm{e}$ \\
\hline 1 & 2.20 & cde & 2.69 & $\mathrm{~b}$ & 15.39 & $\mathrm{~cd}$ & 0.123 & $\mathrm{~cd}$ & 0.00 & e & 0.00 & $\mathrm{e}$ \\
\hline $21 \mathrm{P}$ & 1.80 & $\mathrm{f}$ & 2.05 & $\mathrm{~cd}$ & 12.06 & ef & 0.100 & de & 0.00 & e & 0.00 & $\mathrm{e}$ \\
\hline 5 & 1.96 & ef & 2.33 & $\mathrm{bc}$ & 18.64 & $\mathrm{~b}$ & 0.173 & $\mathrm{a}$ & 0.00 & e & 0.00 & $\mathrm{e}$ \\
\hline 0.5 & 3.65 & $\mathrm{a}$ & 1.79 & $\mathrm{de}$ & 11.46 & $\mathrm{fg}$ & 0.132 & $\mathrm{bc}$ & 1.21 & $\mathrm{a}$ & 0.81 & $\mathrm{a}$ \\
\hline 1 & 2.35 & $\mathrm{~cd}$ & 1.75 & $\mathrm{de}$ & 10.79 & $\mathrm{fg}$ & 0.076 & ef & 0.29 & cde & 0.41 & $\mathrm{bc}$ \\
\hline KIN & 2.81 & $\mathrm{~b}$ & 2.05 & $\mathrm{~cd}$ & 14.09 & $\mathrm{cde}$ & 0.156 & $a b$ & 0.74 & $\mathrm{~b}$ & 0.63 & $\mathrm{ab}$ \\
\hline 5 & 2.45 & $\mathrm{c}$ & 2.50 & $\mathrm{~b}$ & 15.17 & $\mathrm{c}$ & 0.183 & $\mathrm{a}$ & 0.21 & $\mathrm{de}$ & 0.16 & $\mathrm{de}$ \\
\hline
\end{tabular}

${ }^{*}$ means marked with the same letters do not differ significantly at the significance level 0.05 . 
addition of BAP at $1 \mathrm{mg} \cdot \mathrm{dm}^{-3}$ concentration enables the production of a higher number of shoots in stevia than at $0.5 \mathrm{mg} \cdot \mathrm{dm}^{-3}$ concentration. YÜCESAN et al. (2016) demonstrated that addition of BAP and KIN at concentrations between $0.1-2 \mathrm{mg} \cdot \mathrm{dm}^{-3}$ results in the development of an equal number of shoots, yet the longest shoots were obtained when higher KIN concentrations were used $\left(0.5,1\right.$ and $\left.2 \mathrm{mg} \cdot \mathrm{dm}^{-3}\right)$. The study of DAS et al. (2013), kinetin added to the medium at the concentration of $2 \mathrm{mg} \cdot \mathrm{dm}^{-3}$ was the most efficient growth regulator stimulating growth and development of stevia shoots. In the present study, plants growing on medium with the addition of kinetin produced a lower number of shoots than plants growing on media enriched with BAP and 2iP; however, they attained a greater height than the latter combinations. SOLIMANI et al. (2014) showed that the highest number of shoots is formed on medium enriched with $2 \mathrm{mg} \cdot \mathrm{dm}^{-3} \mathrm{BAP}$. This has been confirmed by the results obtained by RAMÍREZMOSQUEDA et al. (2016).

The addition of the following cytokinins to the medium: BAP and $2 \mathrm{iP}$, added at $1-5 \mathrm{mg} \cdot \mathrm{dm}^{-3}$ concentrations influenced shortening of the shoots relative to control plants. Cytokinins applied in the experiment had a negative impact on the elongation of the developed shoots. Shoots of plants propagated on the test media had lower or equal height compared to control plants. The exception consisted of plants propagated on the medium with the addition of $0.5 \mathrm{mg} \cdot \mathrm{dm}^{-3} \mathrm{KIN}(3.65 \mathrm{~cm})$, whose shoots were significantly longer than in plants propagated on MS medium (Table 1). The present study results are similar to the results procured by NOWER (2014), who was also able to demonstrate a positive influence of kinetin on the stevia shoot elongation growth; however, the most favorable result was obtained upon using a medium with the addition of $1.5 \mathrm{mg} \cdot \mathrm{dm}^{-3} \mathrm{KIN}$. Also, the study carried out by DAS et al. (2011) showed that kinetin causes stevia shoot elongation growth. However, in that study, the most favorable result was obtained by using kinetin concentration of $2 \mathrm{mg} \cdot \mathrm{dm}^{-3}$. Conversely, a study conducted by CHOTIKADACHANARONG \& DHEERANUPATTAN (2013) showed that stevia developed longest shoots when explants were introduced onto medium without kinetin addition. Such differences can be attributed to the physiological condition of the explant, which is determined by genetic factors. Multiple passages foster mutation (ROKOSA \& MIKICIUK, 2017) In this study the plants originated from several-year-old culture - in the CHOTIKADACHANARONG \&
DHEERANUPATTAN'S (2013) study plants could be younger or older (there is no information).

The present experiment also demonstrated that all cytokinin types used in the experiment had a stimulatory effect on the number of leaves developed. The highest number of leaves characterized plants propagated on medium with the addition of BAP at 0.5 and $1 \mathrm{mg} \cdot \mathrm{dm}^{-3}$ concentration (Table 1 ). Further increase in its concentration reduced a number of leaves. A reverse situation was observed for media enriched with $2 \mathrm{iP}$ and KIN, where increasing cytokinin concentration resulted in increased number of stevia leaves (Table 1). The study of SIVARAM \& MUKUNDAN (2003) demonstrated a complete inhibition of stevia leaf growth propagated on media enriched with kinetin, and the $4 \mathrm{mg} \cdot \mathrm{dm}^{-3}(8.87 \mu \mathrm{M})$ addition of BAP stimulated their quantity. A similar result was also obtained by ANBAZHAGANA et al. (2010), where kinetin inhibited stevia leaf development, and BAP at $2.5 \mathrm{mg} \cdot \mathrm{dm}^{-3}$ concentration produced the highest number of leaves.

Inhibition of root system formation is the typical effect of cytokinin action. Inhibitory effect of all cytokines on root system formation compared to plants growing on control medium was also observed in the present study. Formation of the short and low number of roots was only observed on the control medium, medium enriched with KIN (independently of the concentration) or 0.5 $\mathrm{mg} \cdot \mathrm{dm}^{-3}$ in BAP (Table 1 ). The above observations are in line with the study of TREJGELL et al. (2013), who demonstrated the inhibitory effect of BAP at a concentration above $0.5 \mathrm{mg} \cdot \mathrm{dm}^{-3}$ on the formation of roots of dandelion (Tarahacum pieninicum), an Asteraceae representative. Moreover, the study carried out by PANICKER et al. (2007) on a chrysanthemum species, Dendranthema grandiflora cv. Arka Swarna (Asteraceae), demonstrated that the highest number of roots was formed on the medium without addition of cytokinins. Furthermore, rhisogenesis was completely stopped when cytokinin concentrations were elevated in the media. Similar results were also obtained by IBRAHIM et al. (2008).

In the majority of cases, the addition of cytokinins produced an increase of stevia plant mass as compared to control (Table 1). Plants propagated on medium with $1 \mathrm{mg} \cdot \mathrm{dm}^{-3} \mathrm{KIN}$ addition constituted an exception, with their mass being similar to control plants. The lowest BAP concentrations $(0.5$ and 1 $\mathrm{mg} \cdot \mathrm{dm}^{-3}$ ) and higher KIN concentrations (2 and 5 $\left.\mathrm{mg} \cdot \mathrm{dm}^{-3}\right)$ had the strongest stimulatory effect on plant mass increase. In the study of CHAKRABARTY \& DATT (2008) on Gerbera jamesonii, also classified in 
the Asteraceae family, a positive impact of cytokinin addition to medium on the formation of plant fresh weight was also observed.

\section{Rooting stage}

In the second experiment, the influence of auxins on the development of stevia in in vitro cultures was examined. It was determined that the addition of auxins at higher concentrations has an inhibitory effect on the development of the above-ground plant part (Figure 2). Stevia rooted in media supplemented with the lowest used IAA concentration $\left(1 \mathrm{mg} \cdot \mathrm{dm}^{-3}\right)$ developed shoots that were longer $(5.24 \mathrm{~cm})$ than in control plants $(4.47 \mathrm{~cm})$. Increased concentration of all auxins used in the experiment resulted in decreasing shoot length (Table 2). Moreover, the study demonstrated that addition of IAA auxin to medium, independently of its concentration and IBA and NAA auxins at lowest concentrations did not influence the number of shoots produced (Table 2; average 1.51). Plants rooted in media supplemented with higher IBA concentrations ( 4 and $8 \mathrm{mg} \cdot \mathrm{dm}^{-3}$ ) and NAA $\left(2,4\right.$ and $\left.8 \mathrm{mg} \cdot \mathrm{dm}^{-3}\right)$ developed a lower number of shoots (average 0.62) than control plants (1.4). The number of stevia leaves on media with IAA addition was similar to control plants (Table 2). However, an increase of the IBA and NAA concentration (to 4 and $8 \mathrm{mg} \cdot \mathrm{dm}^{-3}$ ) resulted in a reduced number of leaves. It was demonstrated that plants propagated on media supplemented with lower IBA concentrations (1 and $2 \mathrm{mg} \cdot \mathrm{dm}^{-3}$ ) are characterized by higher mass relative to control. Increased auxin concentration resulted in reduced plant mass.

The plants produced from 6.08 to 0.16 roots. Similarly to the aforementioned characters, it was also here where the highest number of roots were formed in media with the addition of lower plant growth regulator concentrations -1 and $2 \mathrm{mg} \cdot \mathrm{dm}^{-3}$ (Figure 3). Their highest number was determined in the case of plants propagated on medium supplemented with $1 \mathrm{mg} \cdot \mathrm{dm}^{-3}$ IBA (6.08). With the increase of plant growth regulator concentrations, the number of roots produced decreased (Table 2). Similar results were obtained by RAZAK et al. (2014), where the highest number of roots was developed on the medium with the same composition. These authors were able to produce the same result in the case of root lengththe longest roots were formed on medium with the addition of low IAA concentrations. Increasing concentration of auxins added to media resulted in a reduction of the number and length of roots produced in both in the present experiment, as well as in the work of RAZAK et al. (2014). HWANG (2006) also confirmed the results of the aforementioned studies. The highest number of roots also developed on a medium enriched with $1 \mathrm{mg} \cdot \mathrm{dm}^{-3} \mathrm{IBA}$, and the percentage or plants with developed roots was $100 \%$. Similar results were obtained by ZAYOVA et al. (2013). According to their study, the highest number of roots is produced by stevia on medium with 0.1 $\mathrm{mg} \cdot \mathrm{dm}^{-3}$ IBA $(100 \%$ of plants developed roots), whereas the longest roots can be observed in plants growing on medium with $0.5 \mathrm{mg} \cdot \mathrm{dm}^{-3}$ IAA addition. These results are also confirmed by ANBAZHAGAN et al. (2010) and IBRAHIM et al. (2008).

Conversely, the study of NOWER (2014) showed that the highest number of roots was developed on medium with $0.1 \mathrm{mg} \cdot \mathrm{dm}^{-3}$ IAA, whereas longest roots developed on medium enriched with 1 and 2 $\mathrm{mg} \cdot \mathrm{dm}^{-3}$ IBA. However, similar to the present study, NOWER (2014) showed that highest plants with the highest number of leaves grew on the medium with 1

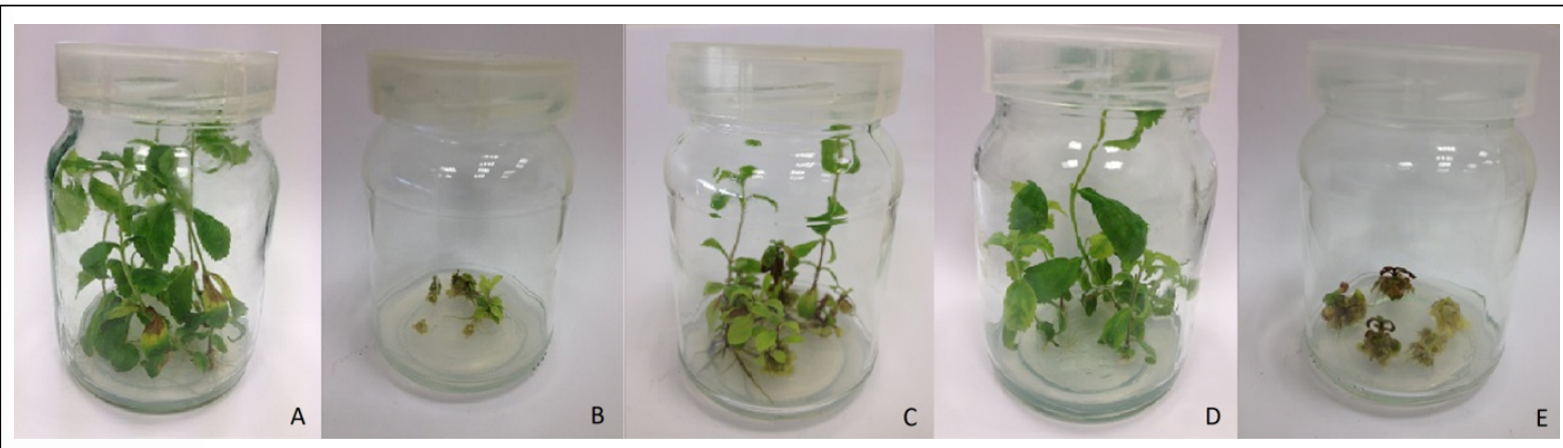

Figure 2 - Stevia growing on MS with $1 \mathrm{mg} \cdot \mathrm{dm}^{-3} \mathrm{IAA}(\mathrm{A}), 8 \mathrm{mg} \cdot \mathrm{dm}^{-3} \mathrm{IBA}(\mathrm{B}), 2 \mathrm{mg} \cdot \mathrm{dm}^{-3} \mathrm{IBA}(\mathrm{C})$, without growth regulators (D) and with $8 \mathrm{mg} \cdot \mathrm{dm}^{-3} \mathrm{NAA}(\mathrm{E})$. 
Table 2 - Mean values of morphological characters of plants propagated on media with a variable content of plant growth regulators (rooting).

\begin{tabular}{|c|c|c|c|c|c|c|c|c|c|c|c|c|}
\hline $\begin{array}{l}\text { Cytokinin concentration } \\
{\left[\mathrm{mg} \cdot \mathrm{dm}^{-3}\right]}\end{array}$ & \multicolumn{2}{|c|}{$\begin{array}{l}\text { Length of shoots } \\
{[\mathrm{cm}]}\end{array}$} & \multicolumn{2}{|c|}{ No. of shoots } & \multicolumn{2}{|c|}{ No. of leaves } & \multicolumn{2}{|c|}{ Fresh weight $[\mathrm{g}]$} & \multicolumn{2}{|c|}{ No. of roots } & \multicolumn{2}{|c|}{$\begin{array}{l}\text { Length of } \\
\text { roots }[\mathrm{cm}]\end{array}$} \\
\hline MS & $4.47^{*}$ & $\mathrm{ab}$ & 1.40 & $a b c$ & 14.24 & $a b$ & 4.80 & $a b c$ & 2.96 & $a b$ & 0.38 & $\mathrm{~cd}$ \\
\hline 1 & 5.24 & $\mathrm{a}$ & 1.68 & $\mathrm{a}$ & 18.48 & $\mathrm{a}$ & 4.16 & abcd & 4.00 & $\mathrm{a}$ & 0.59 & abcd \\
\hline IAA & 4.52 & $a b$ & 1.68 & $\mathrm{a}$ & 16.00 & $\mathrm{a}$ & 3.00 & abcde & 2.38 & abcd & 0.51 & bcd \\
\hline IAA & 2.04 & cdef & 1.40 & $a b c$ & 15.92 & $\mathrm{a}$ & 0.96 & de & 1.24 & cde & 0.45 & bcd \\
\hline 8 & 1.30 & ef & 1.64 & $\mathrm{a}$ & 16.32 & $\mathrm{a}$ & 0.16 & $\mathrm{e}$ & 0.12 & $\mathrm{e}$ & 0.47 & bcd \\
\hline 1 & 3.80 & $a b c$ & 1.36 & $a b c$ & 15.80 & $\mathrm{a}$ & 6.08 & $\mathrm{a}$ & 3.86 & $a b$ & 0.78 & $\mathrm{ab}$ \\
\hline IBA & 2.27 & cde & 1.56 & $a b$ & 14.92 & $\mathrm{ab}$ & 5.48 & $a b$ & 2.24 & bcd & 0.88 & $\mathrm{a}$ \\
\hline ШDА & 0.51 & ef & 0.68 & de & 5.24 & $\mathrm{~cd}$ & 4.00 & abcd & 1.20 & cde & 0.55 & abcd \\
\hline 8 & 0.19 & $\mathrm{f}$ & 0.29 & $\mathrm{e}$ & 3.17 & $\mathrm{~cd}$ & 2.71 & abcde & 0.82 & de & 0.30 & $\mathrm{~d}$ \\
\hline \multirow{4}{*}{ NAA } & 3.33 & bcd & 1.48 & $a b c$ & 14.16 & $a b$ & 5.76 & $\mathrm{a}$ & 2.70 & $a b c$ & 0.73 & $a b c$ \\
\hline & 1.48 & def & 0.96 & bcd & 8.72 & $\mathrm{bc}$ & 2.80 & abcde & 1.18 & cde & 0.55 & abcd \\
\hline & 0.54 & ef & 0.88 & cde & 6.64 & $\mathrm{~cd}$ & 1.88 & bcde & 0.53 & $\mathrm{e}$ & 0.59 & abcd \\
\hline & 0.13 & $\mathrm{f}$ & 0.29 & $\mathrm{e}$ & 1.92 & $\mathrm{~d}$ & 1.04 & cde & 0.16 & e & 0.38 & $\mathrm{~cd}$ \\
\hline
\end{tabular}

${ }^{*}$ means marked with the same letters do not differ significantly at the significance level 0.05 .

$\mathrm{mg} \cdot \mathrm{dm}^{-3}$ IAA addition. What is more, DESHMUKH \& ADE (2012) stated that the highest number of the longest roots was formed in stevia growing on the medium with $0.1 \mathrm{mg} \cdot \mathrm{dm}^{-3}$ IAA. Moreover, such plants exhibited the highest contribution of rooted individuals $(95 \%)$. As in the present study, those authors observed the inhibitory influence of higher auxin concentrations on root formation. Similar

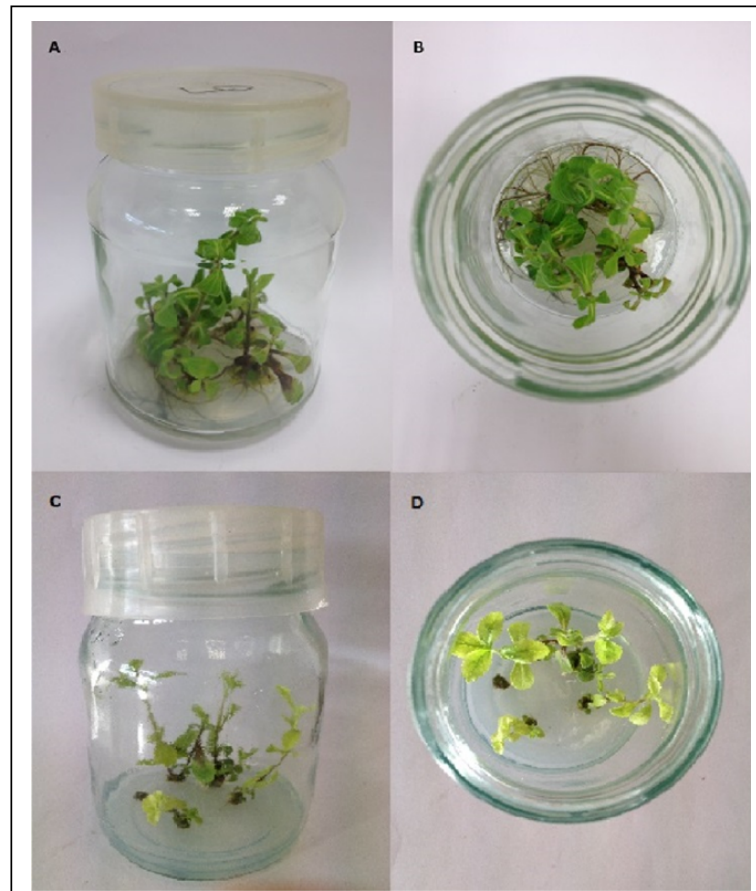

Figure 3 - Stevia (A) and its root system (B) growing on MS with $1 \mathrm{mg} \cdot \mathrm{dm}^{-3} \mathrm{NAA}$ and with $4 \mathrm{mg} \cdot \mathrm{dm}^{-3} \mathrm{IAA}(\mathrm{C}, \mathrm{D})$. 
results were obtained by YÜCESAN et al. (2016), who was able to procure the highest number of roots and $100 \%$ rooted plants on MS medium with 0.25 $\mathrm{mg} \cdot \mathrm{dm}^{-3}$ IAA addition and SOLIMAN et al. (2014), who obtained the highest number of roots and $98.72 \%$ rooted plants on MS medium with $0.5 \mathrm{mg} \cdot \mathrm{dm}^{-3} \mathrm{IAA}$.

The longest roots were developed by stevia shoots rooted on control medium $(2.96 \mathrm{~cm})$ and on media with the lowest $\left(1 \mathrm{mg} \cdot \mathrm{dm}^{-3}\right)$ auxin concentration. Increase in the IAA and NAA concentration (4 and $8 \mathrm{mg}^{\circ} \mathrm{dm}^{-3}$ ) resulted in a reduction of the number of roots formed, as well as their length relative to plants rooted in control medium. Plants propagated on media supplemented with auxins at those concentrations developed roots measuring from $0.12 \mathrm{~cm}$ to $1.24 \mathrm{~cm}$ (Table 2).

The NAA turned out to be the least efficient growth regulator for stevia rooting in RAZAK et al. (2014), HWANG (2006), NOWER (2014), DESHMUKH AND ADE (2012) AND ANBAZHAGAN et al. (2010), as well as in the present study. A completely different result was obtained by THIYAGARAJAN \& VENKATACHALAM (2012). Those authors demonstrated that NAA is a more efficient growth regulator stimulating root formation in stevia than IAA and IBA. As in length of shoots case described, this difference can be attributed to the physiological condition of the explant, which is determined by genetic factors. In THIYAGARAJAN \& VENKATACHALAM'S (2012) study mother plants were 3 months old and there was small number of passages. Conversely, in the study of THIYAGARAJAN \& VENKATACHALAM (2012) the highest number $(8.3)$ of the longest $(6.13 \mathrm{~cm})$ roots were produced on medium enriched with 0.5 $\mathrm{mg} \cdot \mathrm{dm}^{-3}$ NAA. Moreover, those plants exhibited the highest contribution of rooted individuals $(86 \%)$.

\section{CONCLUSION}

On the basis of the conducted study it can be determined, that the used cytokinins: KIN, BAP and 2iP, and auxins: IAA, IBA, and NAA added to mineral medium according to Murashige and Skoog (1962) had a very significant impact on the growth and development of stevia (Stevia rebaudiana Bertoni) in in vitro cultures.

Stevia should be propagated on Murashige and Skoog (1962) mineral medium enriched with 0.5 $\mathrm{mg} \cdot \mathrm{dm}^{-3} \mathrm{BAP}$. Plants propagated on such substrate are characterized by high mass and produce numerous shoots and leaves.

Stevia shoots should be rooted on medium with Murashige and Skoog (1962) medium enriched with $1 \mathrm{mg} \cdot \mathrm{dm}^{-3}$ IBA. Plants growing on such medium were characterized by the highest number of long roots.

\section{ACKNOWLEDGEMENTS}

The research was financed from funds allocated to scientific research of the West Pomeranian University of Technology in Szczecin.

\section{DECLARATION OF CONFLICT OF INTERESTS}

The authors declare no conflict of interest. The founding sponsors had no role in the design of the study; in the collection, analyses, or interpretation of data; in the writing of the manuscript, and in the decision to publish the results.

\section{AUTHORS' CONTRIBUTIONS}

The authors contributed equally to the manuscript.

\section{REFERENCES}

ANBAZHAGAN, M.; In vitro production of Stevia rebaudiana Bertoni. Emirates Journal of Food and Agriculture, v.22(3), pp.216-222, 2010. Available from: <https://doi.org/10.9755/ ejfa.v22i3.4891>. Accessed: Dec. 16, 2018. doi: 10.9755/ejfa. v22i3.4891.

BESPALHOK-FILHO, J. C.; HATTORI, K. Embryogenic callus formation and histological studies from Stevia rebaudiana (Bert.) Bertoni floret explants. Revista Brasileira de Fisiologia Vegetal, v.9(3), pp.185-188. 1997. Available from: <https://www. researchgate.net/profile/Joao Bespalhok/publication/313082119 Embryogenic_callus_formation_and_histological_studies_ from Stevia rebaudiana Bert Bertoni floret explants/ links/59689b74458515e9afa76a08/Embryogenic-callusformation-and-histological-studies-from-Stevia-rebaudiana-BertBertoni-floret-explants.pdf>. Accessed: Dec. 16, 2018.

BONDAREV. N.; et al. Peculiarities of diterpenoidsteviol glycoside production in in vitro cultures of Stevia rebaudiana Bertoni. Plant Science, v.161, p.155-163, 2001. Available from: $<$ https://doi.org/10.1016/S0168-9452(01)00400-9>. Accessed: Dec. 16, 2018. doi: 0.1016/S0168-9452(01)00400-9.

CARBONELL-CAPELLA, J. M.; et al. High pressure processing of fruit juice mixture sweetened with Stevia rebaudiana Bertoni: Optimal retention of physical and nutritional quality. Innovative Food Science and Emerging Technologies, v.18, p.48-56, 2013. Available from: <https://doi.org/10.1016/j.ifset.2013.01.011>. Accessed: Dec. 16, 2018. doi: 10.1016/j.ifset.2013.01.011.

CHAKRABARTY, D.; DATTA, S. K. Micropropagation of gerbera: Lipid peroxidation and antioxidant enzyme activities during acclimatization process. Acta Physiologiae Plantarum, v.30(3), pp.325-331, 2008. Available from: <https://link.springer. com/article/10.1007\%2Fs11738-007-0125-3>. Accessed: dec. 16, 2018. doi: $10.1007 / \mathrm{s} 11738-007-0125-3$.

CHOTIKADACHANARONG， K.; DHEERENUPATTANA, S. Micropropagation and aclimatization of Stevia rebaudiana 
Bertoni. Pakistan Journal of Biological Sciences, v.16(17), pp.887-890, 2013. Available from: <https://scialert.net/abstract/? doi=pjbs.2013.887.890>. Accessed: Dec. 16, 2018. doi: 10.3923/ pjbs.2013.887.890.

DAS, A.; et al. Micropropagation an elite plant: Stevia rebaudiana Bert. International Journal of Agricultural Research, v.6(1), p.40-48, 2011. Available from: <https:// scialert.net/abstract/?doi=ijar.2011.40.48>. Accessed: Dec. 16, 2018. doi: 10.3923/ijar.2011.40.48.

DESHMUKH, S.; ADE, R. In vitro rapid multiplication of Stevia rebaudiana: an important natural sweetener herb. Nusantara Bioscience, v.4(3), p.105-108, 2012. Available from: <http:// citeseerx.ist.psu.edu/viewdoc/download?doi=10.1.1.683.3877\&re $\mathrm{p}=$ rep1\&type $=$ pdf\#page=11>. Accessed: Dec. 16, 2018.

GANTAIT, S.; et al. Stevia: A comprehensive review on ethnopharmacological properties and in vitro regeneration. Sugar Tech, v.17(2), pp.95-106, 2015. Available from: <https://link. springer.com/article/10.1007/s12355-014-0316-3>. Accessed: Dec. 16, 2018.

GASPAR, T.; et al. Plant hormones and plant growth regulators in plant tissue culture. In Vitro Cell. Dev. Biol.-Plant, 32, p.27228, 1996. Available from: <https://doi.org/10.1007/BF02822700>. Accessed: May, 27, 2019. doi: 10.1007/BF02822700.

GEUNS, J.M.C. Stevioside. Phytochemistry, v.64(5), p.913921, 2003. Available from: <https://doi.org/10.1016/S00319422(03)00426-6>. Accessed: Dec. 16, 2018. doi: 10.1016/S00319422(03)00426-6.

GOETTEMOELlER, J.; LUCKE， K. Stewia. Uprawa i wykorzystanie. Wydawnictwo Kubajak: Krzeszowice, 2010. 5-7p. [in polish].

HWANG, S.J. Rapid in vitro Propagation and enhanced stevioside acumulation in Stevia rebaudiana Bert. Journal of Plant Biology, v.49(4), pp.267-270, 2006. Available from: <https://link.springer. com/article/10.1007\%2FBF03031153>. Accessed: Dec. 16, 2018. doi: 10.1007/BF03031153.

IBRAHIM, I.A.; et al. Plant growth regulators affecting in vitro cultivation of Stevia rebaudiana. Sugar Tech, v.10(3), p.254-259, 2008. Available from: $<$ https://link.springer.com/article/10.1007\% 2Fs12355-008-0045-6>. Accessed: Dec. 16, 2018. doi: 10.1007/ s12355-008-0045-6.

KHALIL, S.A.; et al. Selection of suitable propagation method for consistent plantlets production in Stevia rebaudiana (Bertoni). Saudi Journal of Biological Sciences, v.21(6), p.566-573, 2014. Available from: <https://doi.org/10.1016/j.sjbs.2014.02.005>. Accessed: Dec. 16, 2018. doi: 10.1016/j.sjbs.2014.02.005.

KHAN, S.A.; et al. Agrobacterium tumefaciens-mediated transgenic plant and somaclone production through direct and indirect regeneration from leaves in Stevia rebaudiana with their glycoside profile. Protoplasma, v.251(3), p.661667, 2014. Available from: <https://link.springer.com/ article/10.1007\%2Fs00709-013-0568-x>. Accessed: Dec. 16 2018. doi: 10.1007/s00709-013-0568-x.

KUMAR, R. Seed germination of Stevia rebaudiana influenced by various potting media, Octa Journal of Biosciences, v.1(2), pp.143-146, 2013. Available from: < https://search.proquest.com/ openview/327888d1e0c96af2b63f826d1426ddd6/1?cbl=2032 678\&pq-origsite $=$ gscholar $>$. Accessed: Dec. 16, 2018. ISSN: 2321-3663.

LEMUS-MONDACA, R.; et al. Stevia rebaudiana Bertoni, source of a high-potency natural sweetener: A comprehensive review on the biochemical, nutritional and functional aspects. Food Chemistry, v.132, p.1121-1132, 2012. Available from: $<$ https:// doi.org/10.1016/j.foodchem.2011.11.140>. Accessed: Dec. 16, 2018. doi: 10.1016/j.foodchem.2011.11.140.

MATHUR, S.; SHEKHAWAT, G.S. Establishment and characterization of Stevia rebaudiana (Bertoni) cell suspension culture: An in vitro approach for production of stevioside. Acta Physiologiae Plantarum, v.35(3), p.931-939, 2013. Available from: <https://link.springer.com/article/10.1007/ s11738-012-1136-2>. Accessed: Dec. 16, 2018. doi: 10.1007/ s11738-012-1136-2.

NOWER, A.A. In vitro propagation and synthetic seeds production: an efficient methods for Stevia rebaudiana Bertoni. Sugar Tech, v.16(1), p.100-108, 2014. Available from: <https://link.springer. com/article/10.1007\%2Fs12355-013-0228-7>. Accessed: Dec. 16, 2018. doi: 10.1007/s12355-013-0228-7.

PANICKER, B.; et al. Influence of cytokinin levels on in vitro propagation of shy suckering chrysanthemum "Arka Swarna" and activation of endophytic bacteria. In Vitro Cellular and Developmental Biology - Plant, v.43(6), p.614-622, 2007. Available from: <https://link.springer.com/article/10.1007\%2 Fs11627-007-9061-6>. Accessed: Dec. 16, 2018. doi: 10.1007/ s11627-007-9061-6

RAMÍREZ-MOSQUED, M.A.; et al. Micropropagation of Stevia rebaudiana Bert. in temporary immersion systems and evaluation of genetic fidelity. South African Journal of Botany, v.106, p.238-243, 2016. Available from: <https://doi.org/10.1016/j. sajb.2016.07.015>. Accessed: Dec. 16, 2018. doi: 10.1016/j. sajb.2016.07.015.

RAZAK, U.N.A.A.; et al. In vitro micropropagation of Stevia rebaudiana Bertoni in Malaysia. Brazilian Archives of Biology and Technology, v.57(1), p.23-28, 2014. Available from: <http:// www.scielo.br/scielo.php? script $=$ sci arttext\&pid $=\mathrm{S} 1516-$ 89132014000100004\&lng=en\&tlng=en $>$. Accessed: dec. 16, 2018. doi: 10.1590/S1516-89132014000100004.

ROKOSA, M.; MIKICIUK, M.; In vitro regeneration of Fragraria plants. Acta Sci. Pol. Hortorum Cultus, 16(5), 145-158. 2017. Available from: <http://www.acta.media.pl/pl/action/ getfull.php?id=5431>. Accessed: May, 27, 2019. doi: 10.24326/ asphc.2017.5.15.

SIVARAM, L.; MUKUNDAN, U. In vitro culture studies on Stevia rebaudiana. In Vitro Cellular and Developmental Biology - Plant, v.39, pp.520-523, 2003. Available from: < https://link. springer.com/article/10.1079\%2FIVP2003438>. Accessed: Dec. 16, 2018. doi: 10.1079/IVP2003438.

SOLIMAN, H.I.A.; et al. Micropropagation of Stevia rebaudiana Betroni and assessment of genetic stability of in vitro regenerated plants using inter simple sequence repeat (ISSR) marker. Plant Biotechnology, v.31, pp.249-256, 2014. Available from: <https://www.jstage.jst.go.jp/article/plantbi otechnology/31/3/31 14.0707a/ article>. Accessed: Dec. 16, 2018. doi: 10.5511/plantbiotechnology.14.0707a. 
TAVARINI, S.; ANGELINI, L.G. Stevia rebaudiana Bertoni as a source of bioactive compounds: The effect of harvest time, experimental site and crop age on steviol glycoside content and antioxidant properties. Journal of the Science of Food and Agriculture, v.93(9), p.2121-2129, 2013. Available from: <https:// onlinelibrary.wiley.com/doi/full/10.1002/jsfa.6016>. Accessed: Dec. 16, 2018. doi: 10.1002/jsfa.6016.

THIYAGARAJAN, M.; VENKATACHALAM, P. (2012) Large scale in vitro propagation of Stevia rebaudiana (Bert) for commercial application: Pharmaceutically important and antidiabetic medicinal herb. Industrial Crops and Products, v.37(1), p.111-117, 2012. Available from: $<$ https://doi.org/10.1016/j.indcrop.2011.10.037>. Accessed: Dec. 16, 2018. doi: 10.1016/j.indcrop.2011.10.037.

TREJGELL, A.; et al. An efficient system for regenerating Taraxacum pieninicum Pawł. from seedling explants. Acta
Biologica Cracoviensia Series Botanica, v.55(1), p.73-79, 2013. Available from: <https://content.sciendo.com/view/journals/ abcsb/55/1/article-p73.xml $>$. Accessed: Dec. 16, 2018. doi: 10.2478/abcsb-2013-00013.

YÜCESAN, B.; et al. In vitro and ex vitro propagation of Stevia rebaudiana Bertoni with high Rebaudioside - A content-A commercial scale application. Scientia Horticulturae. v.203, p.20-28, 2016. Available from: <https://doi.org/10.1016/j. scienta.2016.03.008>. Accessed: Dec. 16, 2018. doi: 10.1016/j. scienta.2016.03.008.

ZAYOVA, E.; et al. Antioxidant activity of in vitro propagated Stevia rebaudiana Bertoni plants of different origins. Turkish Journal of Biology, v.37, p.106 - 113, 2013. Available from: $<$ https://doi.org/ 10.3906/biy-1204-64>. Accessed: Dec. 16, 2018 doi: $10.3906 /$ biy-1204-64 